\title{
Seroprevalence and risk factors associated to Neospora caninum in dairy cattle herds in the municipality of Pasto, Colombia
}

\author{
Seroprevalencia y factores de riesgo asociados a Neospora \\ caninum en ganado lechero en el municipio de Pasto, Colombia
}

\author{
Darío Cedeño $Q,{ }^{1 *}$ M.Sc, Bibiana Benavides $B,{ }^{1}$ M.Sc. \\ ${ }^{1}$ Universidad de Nariño, Facultad de Ciencias Pecuarias, Programa Medicina Veterinaria, Grupo de \\ investigación de Buiatria, Pasto, Colombia.* Correspondencia: dcedeno@udenar.edu.co
}

Recibido: Agosto de 2011; Aceptado: Febrero de 2012.

\begin{abstract}
Objective. To determine seroprevalence and risk factors associated to Neospora caninum in nonvaccinated dairy cattle against infectious agents of reproductive syndrome in the municipality of Pasto, Colombia. Materials and methods. Farms over 2527 meters over sea level were selected, a total of 238 serum samples of Holstein cows were collected and analyzed using the indirect ELISA test to determine $N$. caninum seropositivity. An epidemiological survey was realized in each herd which included variables related to health and management measures of cattle. A multivariate analysis of binary logistic regression was used with a confidence interval of $95 \%(p<0.05)$ using SPSS19 ${ }^{\circledR}$ program. Results. The estimated prevalence of $N$. caninum was $76.9 \%$. The risk factors associated to neosporosis infection in the analyzed farms are as follows: residues of abortions generally left outdoors and not buried (OR 3.81, 95\% CI 1.5 - 9.6); dogs fed with leftovers (OR 15.44 IC 95\% 1.94-123.22) and bulls allowed to mate with cows (OR 19.68, 95\% CI 2.34 - 165.52). Conclusions. The high prevalence of $N$. caninum and the low abortion rate in dairy herds of the municipality of Pasto corroborated no existence of the disease in all animals serologically positive, but it did suggest that at some point in their lives they were exposed to $N$. caninum. From the identified risk factors in this study, recommendations can be provided for an effective control of reproductive diseases like Neosporosis present in this region.
\end{abstract}

Key words: Abortion, fetal death, parasites, serology (Source: $C A B$ ). 


\section{RESUMEN}

Objetivo. Determinar la seropositividad de $N$. caninum en bovinos no vacunados contra el síndrome reproductivo y los factores de riesgo asociados a la presentación de esta enfermedad en los hatos lecheros del municipio de Pasto, Nariño. Materiales y métodos. Se seleccionaron fincas sobre los $2527 \mathrm{msnm}$. Se analizaron muestras de suero de 238 vacas Holstein mediante la prueba de ELISA indirecta para determinar la seropositividad a $N$. caninum y se realizó una encuesta epidemiológica incluyendo variables sobre el ganado como: medidas sanitarias y de manejo. Se realizó un análisis multivariado mediante regresión logística binaria con un intervalo de confianza del $95 \%(p<0.05)$ utilizando el programa SPSS19 ${ }^{\circledR}$. Resultados. La prevalencia estimada para $N$. caninum fue de $76.9 \%$. Los factores de riesgo asociados a Neosporosis en las fincas estudiadas son los residuos de abortos, que no se entierran y se dejan a la intemperie (OR 5.49; IC 95\% 1.7-17.7), alimentar los perros con desperdicios (OR 15.44 IC $95 \%$ 1.94-123.22) y la monta directa (OR 14.62 IC $95 \%$ 1.55-137.53). Conclusiones. La elevada prevalencia de $N$. caninum y la tasas bajas de abortos en el municipio de Pasto, confirma que la enfermedad no se presenta en todos los animales positivos serológicamente, pero sugiere que en algún momento de su vida fueron expuestos al agente causal. A partir de los factores de riesgo identificados en este trabajo se pueden establecer recomendaciones para un control efectivo de enfermedades reproductivas como la Neosporosis presentes en la región.

Palabras clave: Aborto, muerte fetal, parásitos, serología (Fuente: CAB).

\section{INTRODUCTION}

Bovine neosporosis is a parasitic disease caused by the protozoan Neospora caninum ( $N$. caninum) and it is considered one of the main causes of abortion in cattle worldwide (1). Abortions due to Neosporosis infection have been reported as a substantial financial loss in livestock industry (2). The transmission from an infected cow to its offspring has been identified as the main route of infection. Elimination of $N$. caninum in aborted fetuses is considered one of the most relevant ways to maintain the infection in herds (3).

Dogs have been identified as definitive hosts, where the sexual stage of protozoa develops in the gut forming oocysts eliminated with the feces and then ingested by cattle (4). The asexual phase starts in cows with the formation of tissue cysts and tachyzoites in the intermediate host or fetus. The completion of the epidemiological cycle occurs when dogs ingest infected tissues- aborted fetus or placenta tissue- forming oocysts all over again (5). Drinking water and food, contaminated by dogs or any other carriers not yet identified can cause this infection $(6,7)$.

Abortions can occur sporadically or in outbreaks at any time of gestation (8), but it is more common between the 4th and 6th month of pregnancy (6). It has been reported that there is a higher prevalence in dairy cattle than in beef cattle because of management factors facilitating the spread of the disease (9).
Seroprevalence of $N$. caninum has been reported as follows: in Argentina $64.5 \%$ in cows with clinical history of abortion (10), in Paraguay a seroprevalence of $29.8 \%$ was detected by ELISA and it was identified as the major cause of abortions in meat and milk cattle (11). In Parana, Brazil $15.1 \%$ was found in dairy Holstein breed (12). In Aguascalientes, México $57.5 \%$ seroprevalence was found in cows with a clinical history of abortion (13), similar to those found in dairy herds in Tulcán-Ecuador 51.64 $\%$ (14). In northwestern United States a $24 \%$ of seroprevalence was found; which increases during the winter, attributed to the high density of cattle (15).

In Colombia, $54.1 \%$ of seroreactivity was reported in 357 animals with a history of abortion (16). In Nariño, there have been no epidemiological studies on patterns of $N$. caninum; therefore the objective of this study was to determine the prevalence and risk factors associated with this parasite.

\section{MATERIALS AND METHODS}

A cross-sectional study was conducted to determinate the seroprevalence of $N$. caninum in the municipality of Pasto. The difference among exposed animals and non-exposed animals with the analyzed variables was found as a risk factor.

Study site. This research was conducted in 10 dairy farms in the rural municipality of Pasto, 
located nearby the Galeras Volcano, which belongs to an ecosystem of Lower Mountain according to the Holdridge classification. The ecosystem is characterized by $700 \mathrm{~mm}$ annual precipitation, average temperature of $13.3^{\circ} \mathrm{C}$ and humidity of $60 \%$ to $88 \%$. These farms were extensively managed; cows remain most of the time within fenced pastures, with no physical separation between heifers and adult cows.

Cattle population. The sample size was determined by a simple random sampling strategy, based on cow population in dairy farms according to the 2010 Census Foot and Mouth disease (FMD) vaccination in the municipality of Pasto:

$$
\boldsymbol{n}=\frac{\mathbf{N} * \mathbf{Z}_{\mathbf{2}} * \mathbf{P} *(\mathbf{1}-\mathbf{P})}{\mathbf{N} * \mathbf{e}_{\mathbf{2}}+\mathbf{Z}_{\mathbf{2}} * \mathbf{P} *(\mathbf{1}-\mathbf{P})}
$$

Where:

$\mathrm{N}$ : Number of dairy cows in the municipality (3489)

P: Expected prevalence (40\%)

e: Accepted error (5\%)

Z: Confidence level (90\%)

A total of 238 Holstein cows were sampled, these animals had never been vaccinated against Neosporosis and other reproductive diseases. These animals were in small size herds with and a moderate level of milk production $(15 \mathrm{~kg} /$ cow/day), that corresponds with traditionally managed herds. These farms have information systems about reproductive events and animal identification. The inclusion criteria were: nursing cows ( $>2$ years old) with more than 6 months of permanence in the farms.

Variables. Epidemiological data were collected through a structured survey obtained by a direct interview with the cattle farmer. The included variables were: 1 . Reproductive Managementsynchronization, culling, and type of reproduction (natural or artificial insemination). 2. Animal Health - annual abortion, deworming, and vaccination; 3. Pasture Managementorganic fertilizer and manure as fertilizer. 4. Origin of Replacements Cows (external, same farm or mixed). 5. Biosecurity- water source, elimination of fetuses and placentas. 6 . Presence of animals - sheep, horses, pigs, cats, and dogs.

Sample collection and serological examination. Blood samples $(10 \mathrm{ml})$ were collected by venipuncture of coccygeal vein using sterile tubes without anticoagulant (Vacutainer) which were subsequently taken to the Clinical Veterinarian Diagnostic Laboratory at "Universidad de Nariño". These blood samples were centrifuged (1500 rpm / $5 \mathrm{~min}$ ) in order to obtain the serum which was finally stored at $-20^{\circ} \mathrm{C}$ until it was analyzed.

The presence of antibodies against Neospora caninum were tested using a commercial indirect Enzyme-linked Immunosorbent Assay (ELISA) kit (Uppsala, Sweden, Svanova Biotech ${ }^{\circledR}$ ), following the manufacturer's specifications. The ELISA equipment for the kit was: 1. a lector STAT FAX 3200, 2. Washing equipment STAT FAX 2600 and 3. Incubator Stat Fax 2200.

The $N$. caninum iscom ELISA Kit is designed to detect bovine Neospora-specific antibodies (Immunoglobulin G-IgG) in serum. The kit procedure is based on a solid phase indirect Enzyme Linked Immunosorbent Assay (ELISA). In this procedure, serum samples were exposed to noninfectious Neospora antigen incorporated into iscoms coated onto wells of micro titer strips.

Neospora antibodies (if present in the serum sample) bind parasite antigen in the wells. The HRP conjugate added subsequently forms a complex with these $N$. caninum antibodies. Unbound material is removed by rinsing before the addition of substrate solution. Subsequently a blue color develops which is due to the conversion of the substrate by the conjugate. A positive result is indicated by development of a blue color. The reaction is stopped by addition of the stop solution; the color changes to yellow. The result can be read visually or by a microplate photometer, where the optical density (OD) is measured at $450 \mathrm{~nm}$.

The sensitivity and specificity of the test was $99 \%$ and $96 \%$ respectively. The plates were read at $450 \mathrm{~nm}$ and the results were given in optical density values expressed in percentage of positivity for antibodies to $N$. caninum. The used formula was:

$(\mathbf{p p}) \%$ positivity values $=\frac{\text { sample or negative control }(\text { D corrected })}{\text { positive control }(0 \mathrm{D} \text { corrected })} \times 100$

The control values were within the following limits: positive control optical density (OD) $>0.8$ and $O D$ negative control $<0.15$. To ensure validity, the duplicate of the OD values should not differ more than $25 \%$ from each other. This information was obtained from the Diagnostic Instructions Kit.

Data analysis. The prevalence of antibodies to $N$. caninum was estimated from the ratio of positive results to the total number of examined cattle (17). The association between 
seroprevalence and risk factors was quantified using a multivariate binary logistic regression with a confidence interval of $95 \%$. The significance of the association was estimated by determining Odds Ratio (OR) of each factor with a $p<0.05$. The adjustment of the test was assessed with statistics Hosmer-Lemeshow. Calculations were performed using SPSS $19 \AA$ with the next steps: Analyzer>regression>logistic binary; where the dependent variable was positive or negative to $N$. caninum and variables like risk factors were analyzed as the covariate.

\section{RESULTS}

Percentage of abortions in this study was $7 \%$, but only $2 \%$ were attributed to $N$. caninum infection. The other animals which aborted were positive to other infectious agents such as Brucella abortus, Herpesvirus bovino tipo I and virus of diarrhea bovine.

Medical records of the farms reported placental retention and return to estrus after artificial insemination, increasing the mating per conception; which directly affects open days (140 \pm 20 days). These farms only had records of vaccination against FMD and brucellosis.

The prevalence for $N$. caninum in the municipality of Pasto was of $76.9 \%$ (183 cows seropositive). In nine farms, the seropositivity was over to $60 \%$ and it was lower only in one farm (Farm D.) The results of seroprevalence in each farm are described in table 1.

Table 1. Prevalence of antibodies (IgG) to $N$. caninum in Holstein cows in dairy farms in the municipality of Pasto.

\begin{tabular}{ccccc}
\hline Farm & $\begin{array}{c}\text { Number of } \\
\text { cows }\end{array}$ & $\begin{array}{c}\text { Number } \\
\text { of positive } \\
\text { cows to } \\
\text { Neospora }\end{array}$ & $\begin{array}{c}\text { Number of } \\
\text { negative } \\
\text { cows to } \\
\text { Neospora }\end{array}$ & $\begin{array}{c}\text { Prevalence } \\
\text { (\%) } \\
\text { Neospora }\end{array}$ \\
\hline A & 27 & 22 & 5 & 81.5 \\
B & 25 & 15 & 10 & 60.0 \\
C & 19 & 13 & 6 & 68.4 \\
D & 8 & 3 & 5 & 37.5 \\
E & 22 & 17 & 5 & 77.3 \\
F & 15 & 13 & 2 & 86.7 \\
G & 38 & 24 & 14 & 63.2 \\
H & 23 & 21 & 2 & 91.3 \\
I & 47 & 42 & 5 & 89.4 \\
J & 14 & 13 & 1 & 92.9 \\
TOTAL & 238 & 183 & 55 & 76.9 \\
\hline
\end{tabular}

Three variables were associated with seropositivity to Neosporosis: residues of abortions generally left outdoors and not buried, dogs fed with leftovers and bulls allowed to mate with cows (Table 2).
Table 2. Risk factors associated with seropositivity of Neospora caninum in dairy farms in the municipality of Pasto.

\begin{tabular}{ccccc}
\hline Variable & 20R & $\begin{array}{c}{ }^{1} \text { IC 95\% } \\
\text { Lower }\end{array}$ & Upper & P-Value \\
\hline $\begin{array}{c}\text { Bulls allowed to mate } \\
\text { with cows }\end{array}$ & 14.62 & 1.55 & 137.53 & 0.012 \\
$\begin{array}{c}\text { Abortion Residues } \\
\text { Feeding dogs with } \\
\text { leftovers }\end{array}$ & 5.49 & 1.7 & 17.7 & 0.003 \\
\hline
\end{tabular}

${ }^{1}$ Confidence interval $95 \%$, ${ }^{2}$ Odds ratio, ${ }^{3} \mathrm{P}<0.05$

Other variables showed co linearity or low association such as: management and the serologic results of cattle, presence of other animals (sheep, horses, pigs, cats, and dogs), pasture management (organic fertilizer, manure as fertilizer), and origin of replacements cows (external, same farm or mixed).

\section{DISCUSSION}

The seroprevalence of $N$. caninum within this region is high compared to other parts of the country. In Monteria $10.2 \%$ seropositivity was found in cows with reproductive problems (18) Other studies in Colombia by Zambrano et al (16) reported $54.1 \%$ of seroreactivity in 357 animals with a history of abortion, using the same diagnostic technique ELISA in Antioquia, the prevalence found in Holstein cattle was of $39.9 \%$ and in Brangus cows was 2\% (19).

Abortion is the most commonly reported event in cases of Neosporosis (20); however in this study, the abortion rate was $7 \%$ and it was related to the $N$. caninum infection. This research has questioned the association between infertility or sub fertility and seropositivity to the agent. The majority of these farms have eventually had reproductive problems. The most common issue was the high range of open days exceeding the estimated range and repetition of heats.

It also states that the fetal mummification is a common event in cases of neosporosis described in cases of natural and experimental infections (21), only one farm reported this situation.

The presence of dogs was common in all farms, which cannot be determined statistically as a risk factor because of the co-linearity. However, in a study in Brazil, no association between the presence of dogs in farms with $N$. caninum seropositivity was found (12).

Other authors describe a strong association between the existence of canine defecation in pastures, presence of street dogs and other wild animals (foxes) with the presentation of $N$. 
caninum $(22,23)$. Moreover, feeding dogs with leftovers and residues of abortions represent a risk factor, because the food is contaminated with tachyzoites; starting the cycle in definitive hosts (24).

The elimination of aborted material becomes a major risk factor in this sampled region; contrary to those reported in Aguascalientes, México (13) where no association was found between the provision of aborted fetuses and placental debris with seroprevalence. Fetuses and/or stillbirths, and poor provision of these materials in the farm are conducive to a proliferative environment of this parasite in pasture water and facilities. Animals found within the premises that entered in the parasite cycle may contaminate them because oocysts are environmentally resistant (25).

Mating among cows and bulls is a common practice in this region, which has become a risk factor even though, artificial insemination is allowed in cows during repeats estrus. Experiments conducted in the U.S. showed that venereal transmission is possible with a large number of tachyzoites (26). In this study, two out of three bulls sampled were seropositive for antibodies to $N$. caninum. Benavides et al, consider that there is a strong association between abortions and absence of drainage systems and septic tanks in the Department of Nariño, in regards to the management of wastewater and storm water because this improves the maintenance of $N$.caninum and Leptospira sp (27). However, in these farms there were no risk factors for the disease studied.

In terms of the replacements management of farm raised or purchased cattle, there were no risk factors associated with seropositivity of $N$. caninum. Farmers breeding their own replacement cattle are one relevant mechanism in order to maintain a high prevalence (28).

In conclusion, the results obtained in this research do not show the existing disease in animals that were positive to the serologic test. This suggests that these animals were eventually exposed to the causal agent causing the formation of specific antibodies to the parasite. Finally, it is important to mention that the poor management of aborted animals, feeding dogs with leftovers, and cattle mating are risk factors associated with the seropisivity of $N$. caninum

\section{REFERENCES}

1. Ortega Mora LM, Schares G, Dubey JP. Epidemiology and control of neosporosis and Neospora caninum. J Clin Microbiol 2007; 20:323-367.

2. Dubey JP, Schares G. Neosporosis in animals-the last five years. Vet Parasitol 2011; 180(1-2):90-108.

3. Maley S, Buxton D, Rae A, Wright S, Schock A, Bartley Pet al. The pathogenesis of neosporosis in pregnant cattle: inoculation at mid-gestation. J Comp Path 2003; 129:186-195.

4. Williams DJL, Hartley CS, Björkman C, Trees AJ. Endogenous and exogenous transplacental trasmission of Neospora caninum how the route of transmission impacts on epidemiology and control of disease. Parasitol 2009; 136:1895-1900.

5. Atkinson R, Harper P, Reichel M, Ellis J. Progress in the serodiagnosis of Neospora caninum infection of cattle. Parasitol Today 2000; 16:110-114.
6. McAllister MM, Bjôrkman C, AndersonSprecher R, Rogers DG. Evidence of poitsource exposure to Neospora caninum and protective immunity in a herd of beef cows. J Am Vet Med Assoc 2000; 217:881-887.

7. Schares C, Bârwald A, Staubach C, Sôndgen P, Rauser M, Schrôder R et al. p38- avidityELISA: examination of herds experiencing epidemic or endemic Neospora caninum associated bovine abortion. Vet Parasitol 2002; 106:293-305.

8. Williams D, Guy C, Smith R, Guy F, Mcgarry J, Mckay J, Trees A. First demonstration of protective immunity against foetopathy in cattle with latent Neospora caninum infection. Int J Parasitol 2003; 33:1059-1065.

9. Munhoz AD, Pereira MJS, Flausino W, Lopes CWG. Neospora caninum seropositivity in cattle breeds in the South Fluminense Paraíba Valley, state of5 Rio de Janeiro. Pesq Vet Bras 2009; 29:29-32. 
10. Venturini MC, Venturini $L$, Bacigalupe $D$, Machuca M, Echaide I, Basso W et al. Neospora caninum infections in bovine foetus and dairy cows with abortions in Argentina. J Parasitol 1999; 29:1705-1708.

11. Osawa T, Wastling J, Acosta L, Ortellado C, Ibarra J, Innes E. Seroprevalence of Neospora caninum infection in dairy and beef cattle in Paraguay. Vet Parasitol 2002; 110:17-23.

12. Guimaraes JS, Souza SLP, Bergamaschi DP, Gennari SM. Prevalence of Neospora caninum antibodies and factors associated whit their presence in dairy cattle of the north of Parana state, Brazil. Vet Parasitol 2004; 124:1-8.

13. Gutierrez J, Cruz-Vazquez C, Medina L, Valdivia A, Islas E, Garcia Bazquez Z. Factores de manejo asociados con la seroprevalencia a la infeccion por Neospora caninum en ganado lechero de Aguascalientes, México. Vet Mex 2007; 38:261-270.

14. Cruz MM. Identificación del parásito Neospora caninum por medio del método de ELISA, en las haciendas ganaderas del cantón de Tulcán en la provincia del Carchi. [Trabajo de grado]. Ecuador: Univesidad de las Americas; 2011. URL Disponible en: http://dspace.udla.edu.ec/ bitstream/123456789/402/1/TMVZ-201111.pdf.

15. Sanderson W, Gay M, Baszler V. Neospora caninum seroprevalence and associted risk factors in beef cattle in the northwestern United Stated. Vet Parasitol 2000; 90:15-24.

16. Zambrano J, Cotrino V, Jimenez C, Romero M, Guerrero B. Evaluación serológica de Neospora caninum en bovinos en Colombia. Rev Acovez 2001; 26:5-10.

17. Thrusfield M. Veterinary Epidemiology. Third edition. Australia: Blackwell publishing; 2005.

18. Oviedo T, Betancur C, Mestra A, Gonzales M, Reza L, Calonge K. Estudio serologico sobre neosporosis en bovinos con problemas reproductivos en Monteria, Córdoba, Colombia. Rev MVZ Cordoba 2007; 12: 929-933.
19. López G, Restrepo B, Restrepo M, Lotero MA, Murillo V, Chica A et al. Estudio para evidenciar la presencia de Neospora caninum en bovinos de la hacienda San Pedro en el municipio de Fredonia. Antioquia. Colombia. Rev CES MVZ 2007; 2(1):16-20.

20. Dubey JP. Review of Neospora caninum and neoporosis in animals. Korean J Parasitol 2003; 41:1-16.

21. Moore DP. Neosporosis in South America. Vet Parasitol 2005; 127:87-97.

22. Schares G, Barwald A, Staubach C, Ziller M, Kloss D, Schroder $R$ et al. Potential risk factors for bovine Neospora caninum infection in Germany are not under control of the farmers. Parasitol 2004; 129:301-309.

23. Hobson JC, Duffield TF, Kelton D, lissemore K, Hietala SK, Leslie KE. Risk factors associated with Neospora caninum abortion in Ontario Holstein dairy herds. Vet Parasitol 2005; 127:177-188.

24. Fernández E, Gómez M, Miro G, Alvarez G, Pereira J, Frisuelos C et al. Seroprevalence and risk associated with Neospora caninum infection in different dog populations in Spain. Vet Parasitol 2008; 152:148-151.

25. Neto AFA, Bandini LA, Nishi SM, Soares RM, Driemeier D, Antoniassi NAB et al. Viability of sporulated oocysts of Neospora caninum after exposure to different physical and chemical treatments. J Parasitol 2011; 97:135-139.

26. Ferre I, Serrano-Martínez E, Martínez A, Osoro K, Mateos-Sanz A, del Pozo I et al. Effects of reinfection with Neospora caninum in bulls on parasite detection in semen and blood and immunological responses. Theriogenol 2008; 69:905-911.

27. Benavides B, Jurado C, Cedeño D. Factores de riesgo asociados a aborto bovino en la Cuenca lechera del departamento de Nariño. Rev MVZ Córdoba 2010; 15(2):2087-2010.

28. Otranto F, Llazari A, Testini G, Traversa D, Regalbono AF, Badan M. Seroprevalence and associated risk factors of Neosporosis in beef and dairy cattle in Italy. Vet Parasitol 2003; 118:7-18. 